\title{
A FARMING PICTURE : ALL-GRASS WINTERING IN SOUTHLAND
}

\author{
D. T. MILLER \\ Farmer, Orefi
}

From THE first association of man and beast, grass of one type or another has played a very important part in the feeding of farm animals. Over the past twelve to fourteen years, all-grass wintering has been carried out with some success, but during the past four to five years the Ministry of Agriculture and Fisheries has launched a very comprehensive programme of instruction in this form of wintering. In more recent years, Grasslands Division, DSIR, has developed some excellent grasses that are durable under heavy stocking and of high.protein value.

\section{WHY I CHANGED TO ALL-GRASS}

After growing swedes for most of my farming life, I felt sure there must be a better way of wintering than feeding a crop that is predominantly water, and which would also be easier as far as labour was concerned.

Five years ago I stopped wintering on swedes because I wanted to have my sheep in less mud, to lower the labour input, and to increase stock numbers and eventually profitability.

Four years ago I grew 4 ha (10 acres) of choumoellier and harvested 102 tonnes (100 tons) of silage; this was of quite good nutritional value but cost too much. The silage was put in on a contract basis and, as well as this cost, there was also the expense of barriers that were used only at feeding-out. In addition to the choumoellier and silage, it seemed necessary to use 480 bales of hay, this being fed prior to and after using this system. Three years ago I converted to all-grass wintering. After three years of quite successful wintering under varied winter conditions, I am now satisfied to continue with this system until a better method of wintering is developed.

The following summarizes how the 93 ha (230 acres) has been farmed over the past five years.

1968 - 22 ha (55 acres) of cash crop and 6 ha ( 14 acres) swedes were grown, 1,900 bales of hay used; stock was 1,036 ewes and rams. 
1969 - 17 ha (43 acres) crop, 5 ha (13 acres) choumoellier, 102 tonnes (100 tons) silage, 480 bales hay used; 1,196 ewes and rams.

1970 (first year all-grass) -15 ha (37 acres) crop, 4 ha (9 acres) swedes, 194 bales hay; 1,167 ewes and rams.

1971 — 30 ha (74 acres) crop, 576 bales hay; 1,458 ewes, rams, ewe lambs (160 ewe lambs).

1972 - 31 ha (77 acres) crop, 1,150 bales hay, 4 tons oats: 1,495 ewes, rams, ewe lambs ( 380 ewe lambs).

Thus, in the last five years, sheep numbers have increased by 459,328 being added in the last two years as my knowledge af allgrass wintering and management has increased.

\section{HOW THE SYSTEM WORKS}

The all-grass wintering system is best started about February or March when most farmers are thinking about flushing their ewes prior to mating. I consider it better to flush all the ewes in one mob on a quick rotation so that they have plenty of feed to pravide good liveweight gains, and still leave adequate' pasture for the winter.

Most of my paddocks are between 6 and 6.5 ha (14 and 16 acres) and I feel I get a better utilization of grass at flushing time by dividing them into two. This policy is followed until about the end of April when I gradually tighten up in preparation for the winter programme. Before winter starts, it is advisable to plan the winter programme so that there is a 55- to 60-day rotation on grass, excluding sacrifice paddocks. This planning is essential to be able to assess how one intends getting through the winter with a minimum of complications. The main objective at this stage, in preparing a plan, is to have as much grass as possible at lambing time.

The question may arise as to how grass can be eaten throughout winter and still be in good supply for the spring. The answer is simple. Having applied fertilizer, this continues to be returned to the pasture in the form of dung and urine, and all that is needed to promote growth is sunlight. These components working together will without doubt result in a good sole of grass by lambing time.

Best results are achieved by stocking and grazing aver the winter months at between 740 and 990 sheep/ha. This may mean 
that a 6.5 ha paddock would have to be divided into four to six so-called units, depending on the number of sheep in the mob. Twelve to fourteen days after grazing, and given reasonable weather conditions, the regrowth of these pastures is quite amazing and one can visualize the growth and pasture potential by springtime.

\section{DAYS PER BREAK}

A 5 ha (12 acre) paddock subdivided into six gives a unit size 0.8 ha ( 2 acres) on which the flock can be held for two days. If grass is in short supply, a flock of approximately 1,400 would consume the best part of a unit on the first day, and hay at the rate of one bale per hundred could be fed on the second day. In the event of fairly continuous wet weather, a sacrifice paddock is used to cater for the flock and hay is fed at the rate of two bales per hundred.

The sacrifice paddock is generally one of two types, a stubble, or a pasture intended for ploughing in the spring. Whichever one of these is used, the flock should be given an hour or two on grass every three to four days to maintain good stock health.

\section{FENCING AND LABOUR}

Subdividing paddocks into six does not mean hard labour in shifting electric fences. On an average, I- shift approximately $262 \mathrm{~m}$ (13 chains) of fence every two days and find this relatively easy with mechanized winding apparatus. This operation is made simple by being able to drive to work in the farm utility and it is more pleasant to walk round on pasture, either grazed or ungrazed, than in a swede paddock.

After all-grass farming for three years, the following four points have become very apparent:

(1) Lower fertilizer bills.

(2) Low cost quality feed:

(3) Increased- stock.

(4) Low labour input.

First, fertilizer application has been almost halved without any detrimental effects being apparent. Where once I was applying 500 to $560 \mathrm{~kg} / \mathrm{ha}$ of fertilizer on all pastures each year, I now apply $310 \mathrm{~kg} / \mathrm{ha}$. 
No other method of wintering spreads fertilizer in the form of dung and urine round the farm as effectively as this system. It is not going on only one paddock, or being spread along under trees where it is of no use: at all, or going on to the floor of a shed where it must be carted out on to the pasture; at some expense; it is going back directly to the pasture whence it came.

Grass is without a doubt an excellent, low-cost, quality feed and it is over to the management and ability of the individual farmer to ensure that it is used in the most efficient way possible. Last year a friend of mine was wintering 1,200 ewes on swedes and in August took 41 from his flock because they were in very poor condition. Asked what he did with them, he replied that he had put them on to some good grass. My contention is this: Why put them on swedes till they become sick; why not give the whole flock good grass? It should not be thought that I am condemning swedes. However, I do believe I have given up growing them for a far superior method of wintering sheep.

\section{TREADING}

There appears to be no treading damage and the pastures seem to be more weed-free today than they we're four years ago. Grass grub is not apparent on the property and I consider that the intensive stocking over the winter months has helped curb their activity.

\section{CROPPING}

Over the last three years, the first-year wheat crops have shown a substantial increase in yields. In the 1971 harvesting season, the first crop yielded 7,330 kg/ha (109 bu/acre) and in 1972 $7,465 \mathrm{~kg} / \mathrm{ha}$ (111 bu/acre). While oat crops have not shown an increase since the all-grass system was adopted, they have been averaging between 6,640 and $6,730 \mathrm{~kg} / \mathrm{ha}$ (148 and $150 \mathrm{bu} /$ acre) over the last five years. The reason oat yields have not increased is probably because the crop rotation now is from grass, two crops of wheat, one of oats, and then back to grass. The duration of these paddocks in crop may be extended in the future as I consider it possible to grow crops for four or five years without detrimental effects on soil structure or crop yields.

\section{CONCLUSION}

I have enjoyed the challenge in making the change to all-grass farming and at this stage feel I am accomplishing exactly what 
I set out to do three years ago. This method is not just a young man's way of farming; it is for the old and young alike and it is to be hoped that more farmers will make the change in the near future. I consider all-grass farming to be an easier way of wintering flocks, with low capital outlay, increased profitability and low labour input. 